\title{
Criza celiacă, formă atipică de debut al bolii celiace la adolescent - prezentare de caz
}

\author{
Daniela Ciobanu, Lorena Elena Meliț, Ana-Maria Șimon, Nicoleta Tomșa, \\ Cristina Oana Mărginean \\ Clinica Pediatrie, Spitalul Clinic Județean de Urgență, Tg. Mureş, România
}

\begin{abstract}
REZUMAT
Boala celiacă $(\mathrm{BC})$ este o afecțiune sistemică mediată imun determinată de dieta cu gluten la indivizii susceptibili genetic. Criza celiacă este o afecțiune rară, dar cu potențial letal, care poate apărea în cadrul bolii celiace sau ca prima manifestare a acesteia.

Prezentarea cazului. Adolescent în vârstă de 15 ani, cu istoric personal de anemie pentru care nu a urmat tratament corespunzător, s-a internat pentru scaune semiconsistente steatoreice, scădere ponderală, inapetență, fatigabilitate, somnolență, cu debut de aproximativ 10 zile. Analizele de laborator efectuate în momentul prezentării au evidențiat următoarele: trombocitoză, anemie feriprivă, ușoară creștere a transaminazelor, hiperbilirubinemie mixtă, cu predominanța celei indirecte, hiponatremie. A fost exclusă o etiologie infecțioasă a simptomatologiei, iar markerii serologici pentru boala celiacă au fost pozitivi. S-a stabilit diagnosticul de criză celiacă, ca formă de debut a bolii celiace, pe baza simptomatologiei, a valorii crescute a anticorpilor antitransglutaminază (>10x valoarea normală) și a celor de tip antiendomisium pozitivi. Pe parcursul internării, s-a administrat tratament simptomatic, tratament de reechilibrare hidroelectrolitică și a fost inițiată dieta fără gluten. La 3 luni de la inițierea dietei fără gluten, evoluția clinică a pacientului a fost favorabilă, iar parametrii de laborator s-au ameliorat considerabil, cu negativarea anticorpilor antiendomisium și scăderea marcată a valorii anticorpilor antitransglutaminază.

Concluzii. Criza celiacă trebuie luată în considerare în diagnosticul diferențial al tuturor pacienților care prezintă diaree cu debut brusc, tulburări metabolice și scădere în greutate după ce a fost exclusă o etiologie infectioasă, iar recunoașterea acesteia este importantă și facilitează tratamentul prompt.

Cuvinte cheie: boală celiacă, criză celiacă, anticorpi antitransglutaminază,
\end{abstract} anticorpi antiendomisium, adolescent

\author{
Abrevieri \\ $\mathrm{BC}$ - boală celiacă \\ HLA - antigen leucocitar uman \\ Hgb - hemoglobină \\ Hct - hematocrit \\ VEM - volumul eritrocitar mediu \\ ALT - alaninaminotransferaza \\ AST - aspartataminotransferaza \\ Bit - bilirubina totală
}

\author{
BiD - bilirubina directă \\ $\mathrm{Na}-$ sodiu \\ VSH - viteza de sedimentare a hematiilor \\ PCR - proteina $\mathrm{C}$ reactivă \\ IRM - imagistică prin rezonanţă magnetică \\ anti-tTG - anticorpi antitransgutaminază tisulară \\ EMA - anticorpi antiendomisium
}

\section{INTRODUCERE}

Boala celiacă (BC) este o afecțiune sistemică mediată imun determinată de dieta cu gluten la indivizii susceptibili genetic. Aceasta este caracterizată de prezența unei combinații variabile dintre manifestările clinice, anticorpii specifici, haplotipurile HLADQ2 sau HLA-DQ8 și a enteropatiei [1]. BC prezintă o etiologie multifactorială care implică interacțiunea dintre factorii genetici, gluten și factorii de mediu [2]. Prevalența globală a bolii celiace este cuprinsă între $0,7 \%$ și $1,4 \%$, în funcție de vârstă, sex și locația geografică. În Europa, prevalența acesteia este de $0,8 \%$ [3]. În ceea ce privește prevalența bolii celiace în România, datele disponibile sunt limitate, fiind raportată în 2003 o prevalenţă de 2,22\% în rândul populației adulte [4]. 
$\mathrm{BC}$ este frecvent subdiagnosticată ca urmare a variabilității semnelor și simptomelor clinice. Simptomele tipice includ scaune diareice, distensie abdominală, dureri abdominale, scădere în greutate până la hipotrofie staturo-ponderală [5]. Simptomele extraintestinale apar ca urmare a malabsorbției cronice a micronutrienților. Anemia feriprivă, una dintre principalele manifestări extraintestinale, precede de cele mai multe ori diagnosticul și, în multe cazuri, este cea care determină efectuarea unor investigații suplimentare pentru boala celiacă. Alte manifestări extraintestinale sunt reprezentate de dermatita herpetiformă, modificări ale densității osoase, infertilitate, manifestări neurologice, invaginația intestinală [6], artrită/artralgii, stomatită aftoasă recurentă, afecțiuni ale smalțului dentar, creșterea transaminazelor [7]. BC poate fi asimptomatică, caz în care pacienții pot fi diagnosticați prin screening, indicat doar în cazul grupurilor cu risc crescut [8].

O altă formă de prezentare a bolii celiace este criza celiacă, o afecțiune rară, dar cu potențial letal. Din punct de vedere clinic, aceasta este caracterizată de distensie abdominală, diaree severă, vărsături care vor duce la deshidratare și instabilitate hemodinamică, hipoproteinemie, tulburări electrolitice și metabolice precum hipokaliemie, hiponatremie, hipocalcemie, hipomagneziemie [9]. Din cauza debutului acut și progresului rapid al simptomelor gastrointestinale, pacienții necesită de obicei spitalizare. Recunoașterea acestei afecțiuni poate fi dificilă din punct de vedere clinic. Diagnosticul crizei celiace se pune pe baza simptomatologiei acute, a serologiei pozitive pentru boala celiacă și a examenului histopatologic. Tratamentul constă în suport hidro-electrolitic și nutrițional în faza acută, corticoterapie în formele severe și o dietă fără gluten pe termen lung [10].

Prezentăm acest caz cu scopul de a sublinia debutul atipic al BC la un adolescent și dificultăţile legate de diagnosticul în cazul crizei celiace.

\section{PREZENTAREA CAZULUI}

\section{Motivele internării}

Adolescent în vârstă de 15 ani, cu istoric personal de anemie, pentru care nu a urmat tratament corespunzător, s-a internat pentru scaune semiconsistente steatoreice (2-3 scaune/zi), scădere ponderală de aproximativ ( $8 \mathrm{~kg}$ în 10 zile) inapetență, fatigabilitate, somnolență, cu debut de aproximativ 10 zile.

\section{Aspecte clinice}

Examenul obiectiv de la momentul internării a evidențiat ochi încercănați, tegumente palide, turgor cutanat diminuat, țesut adipos slab reprezentat, dis- tensie abdominală marcată și abdomen dureros difuz la palpare. Greutatea a fost de $49 \mathrm{~kg}$, înălțime de 170 $\mathrm{cm}$, cu un indice de masă corporală de $17 \mathrm{~kg} / \mathrm{m}^{2}$.

\section{Criterii de diagnostic}

Analizele de laborator de la momentul internării au evidențiat următoarele elemente patologice: trombocitoză $(605.000 / \mu 1)$, anemie moderată $(\mathrm{Hgb} 9,4$ g/dl, hct 33,8\%, VEM 57 fl, hipocromie moderată cu rare hematii în țintă), valori scăzute ale sideremiei $(3,69$ $\mu \mathrm{mol} / \mathrm{l})$ și feritinei $(5,7 \mathrm{ng} / \mathrm{ml})$, ușoară creștere a transaminazelor (ALT 35,1 U/1, AST 39,8U/1), hiperbilirubinemie mixtă cu predominanța celei indirecte (BiT 3,03 mg/dl, BiD 0,84 mg/dl) și hiponatremie ușoară (Na 134 mmol/l). Examinarea scaunului pentru antigene virale și coprocultura au fost negative, iar serologia pentru hepatită virală A a fost negativă. Markerii inflamatori (VSH, PCR) și albumina serică au fost în limite normale. Serologia pentru boală celiacă a fost pozitivă: anti-tTG crescuți $(616,8$ U/1) și EMA pozitivi. La ecografia abdominală, s-au observat anse intestinale destinse, cu conținut predominant lichidian, pereți intestinali hiperecogeni, peristaltism accentuat; iar IRM-ul abdominal a evidențiat o distensie semnificativă a anselor intestinale, cu acumulare de fluid și gaze, fără îngroșare de pereți, cu excepția unei zone la nivelul ileonului, și limfonoduli reactivi mezenterici.

Astfel, s-a stabilit diagnosticul de criză celiacă ca formă de debut a bolii celiace pe baza simptomatologiei, a valorii crescute a anti-tTG $(>10 \mathrm{x}$ valoarea normală) și a celor de tip EMA pozitivi.

\section{Tratament şi monitorizare}

Am administrat perfuzii de rehidratare, simptomatice (Smecta, Metoclopramid, Hidrasec, Espumisan), probiotice și am recomandat inițierea dietei fără gluten, cu îmbunătățirea parametrilor clinici și ameliorarea celor paraclinici. La externare, s-a recomandat dietă fără gluten, simptomatice și revenire pentru reevaluare clinico-biologică.

La 3 luni de la inițierea dietei fără gluten, evoluția clinică a pacientului a fost favorabilă (greutate 63 $\mathrm{kg}$ ), iar parametrii de laborator s-au ameliorat considerabil: Hgb 11,1 g/dl, VEM 66,1 fl, Hct 35,9\%, AST (22 U/l), ALT (16,3 U/1), BiT (0,98 mg/dl), BiD (0,34 $\mathrm{ml} / \mathrm{dl}$ ), EMA s-au negativat, iar anti-tTG au ajuns la valoarea de $28,8 \mathrm{U} / \mathrm{ml}$.

\section{DISCUȚII}

$\mathrm{BC}$ este o boală mediată imun caracterizată prin simptome de malabsorbție și atrofia vilozitară declanșată de gluten la indivizii susceptibili genetic. 
Inițial, a fost considerată ca fiind o afecțiune rară a copilăriei, dar s-a dovedit că afectează toate grupele de vârstă [11]. Aceasta este caracterizată de prezența autoanticorpilor specifici direcționați împotriva transglutaminazei tisulare, gliadinei deaminate, endomisiumului, haplotipurile HLA-DQ2, HLA-DQ8 şi modificări histopatologice intestinale [7]. În mod similar, vârsta pacientului descris mai sus a fost de 15 ani.

BC la copii se manifestă frecvent cu simptome gastrointestinale (diaree cronică, vărsături, inapetență, distensie abdominală, dureri abdominale, hipotrofie staturală). De asemenea, copiii pot prezenta simptome extraintestinale sau pot fi chiar asimptomatici. Uneori, $\mathrm{BC}$ poate prezenta un debut acut sub forma crizei celiace. Criza celiacă prezintă de obicei manifestări gastrointestinale severe, hipoproteinemie, tulburări electrolitice și metabolice care necesită spitalizare [12]. Criza celiacă este termenul utilizat în cazul pacienților care prezintă o simptomatologie acută şi severă, cu potențial fatal. Aceasta poate fi prima formă de manifestare sau poate fi o complicaţie a pacienților diagnosticați cu boală celiacă [9]. În mod similar, am descris cazul unui adolescent aparent sănătos, care a prezentat diaree, vărsături, hiponatremie şi scădere în greutate, ca debut al bolii celiace, manifestări care fac parte din spectrul simptomatic al crizei celiace. Jamma şi colab. au elaborat o serie de criterii pentru diagnosticul crizei celiace la pacienții adulți [9]. Aceasta a fost definită ca: debut acut sau progresia rapidă a simptomelor gastrointestinale atribuibile bolii celiace care necesită spitalizare și/sau nutriție parenterală, împreună cu cel puțin 2 dintre următoarele: semne de deshidratare severă, inclusiv instabilitate hemodinamică; afectare neurologică; disfuncție renală, cu un nivel ale creatininei peste $2,0 \mathrm{~g} / \mathrm{dl}$; acidoză metabolică, $\mathrm{pH}$ mai mic de 7,35; hipoproteinemie (nivel de albumină sub 3,0 g/dl); anormalii electrolitice (hipernatremie/hiponatremie, hipocalcemie, hipokaliemie sau hipomagneziemie); pierderea în greutate mai mult de 4,5 kg [9]. Dat fiind faptul că datele din literatura de specialitate sunt limitate în ceea ce privește criteriile de diagnostic al crizei celiace, marea majoritate acestora provenind din studii efectuate pe populația adultă, grupele de vârstă ale copiilor și adolescenților rămân mai puțin

\section{BIBLIOGRAFIE}

1. Husby S, Koletzko S, Korponay-Szabó IR et al. European Society for Pediatric Gastroenterology, Hepatology, and Nutrition Guidelines for the Diagnosis of Coeliac Disease. J Pediatr Gastroenterol Nutr. 2012;54(1):136-60.

2. Sollid LM, Lie BA. Celiac disease genetics: current concepts and practical applications. Clin Gastroenterol Hepatol. 2005;3:843-51. studiate. Astfel, în cazul pacientului nostru, au fost îndeplinite următoarele criterii din cele descrise mai sus: debutul acut al simptomelor intestinale care au necesitat spitalizare, hiponatremie și pierderea în greutate. Unii autori au subliniat că această formă de prezentare a bolii celiace este declanșată de un factor, cum ar fi intervenția chirurgicală, infecțiile, sarcina [9], hipoproteinemia, nerespectarea dietei fără gluten, medicamentele anticolinergice [13]. Acești factori ar declanșa o activare a sistemului imunitar cu inflamație severă a mucoasei intestinale și la o perturbare a motilității intestinale normale [9]. În cazul nostru, nu am identificat în istoricul personal intervenție chirurgicală recentă sau utilizarea anticolinergicelor, iar infecția intestinală a fost exclusă pe parcursul internării. Singurul factor declanșator plauzibil ar putea fi neinițierea unei diete fără gluten în condițiile unei boli celiace preexistente, care nu a fost diagnosticată.

$\mathrm{Cu}$ toate că asocierea dintre sindromul Gilbert și BC a fost descrisă în literatură [14], există puține date referitoare la acest aspect. Astfel, în cazul nostru, hiperbilirubinemia mixtă cu predominanța bilirubinei indirecte, inapetența prelungită și aportul caloric scăzut din ultimele zile anterior prezentării sugerează posibila asociere a unui sindrom Gilbert.

Atitudinea terapeutică în criza celiacă presupune reechilibrarea hidroelectrolitică, suport nutriţional și inițierea dietei fără gluten. În cazurile severe, este necesară și administrarea corticoterapiei [10]. În acest caz, reechilibrarea hidroelectrolitică și iniţierea dietei fără gluten au avut un rezultat favorabil.

\section{CONCLUZII}

Diagnosticul crizei celiace reprezintă o provocare, în special în cazul pacienților care nu sunt cunoscuți cu boală celiacă. Așadar, întotdeauna trebuie luată în considerare în diagnosticul diferențial al tuturor pacienților care prezintă diaree cu debut brusc, cu tulburări metabolice și scădere în greutate, după ce a fost exclusă o etiologie infecțioasă. În concluzie, considerăm că recunoașterea debutului acut al bolii celiace sub forma crizei celiace este importantă şi facilitează tratamentul prompt al acesteia.

Conflict of interest: none declared Financial support: none declared

3. Singh P, Arora P, Strand TA et al. Global Prevalence of Celiac Disease: Systematic Review and Meta-analysis. Clin Gastroenterol Hepatol. 2018;16(6):823-836.e2.

4. Dobru D, Pascu O, Tanță M et al. The prevalence of coeliac disease at endoscopy units in Romania: routine biopsies during gastroscopy 
are mandatory (a multicentre study). Rom J Gastroenterol. 2003; 12:97-100.

5. Glissen Brown JR, Singh P. Coeliac disease. Pediatr Int Child Health. 2019;39(1):23-31.

6. Al-Bawardy B, Chamil Codipilly D, Rubio-Tapia A et al. Celiac disease: a clinical review. Abdom Radiol. 2017;42(2):351-360.

7. Husby S, Koletzko S, Korponay-Szabo I et al. European Society Paediatric Gastroenterology Hepatology and Nutrition Guidelines for Diagnosing Coeliac Disease 2020. J Pediatr Gastroenterol Nutr. 2020;70:141-156.

8. Lindfors K, Ciacci C, Kurppa K et al. Coeliac disease. Nat Rev Dis Primers. 2019;5(1):3

9. Jamma S, Rubio-Tapia A, Kelly CP et al. Celiac crisis is a rare but serious complication of celiac disease in adults. Clin Gastroenterol Hepatol. 2010;8:587-590.
10. Balaban DV, Dima A, Jurcut $C$ et al. Celiac crisis, a rare occurrence in adult celiac disease: A systematic review. World J Clin Cases. 2019;7(3):311-319.

11. Green PHR, Cellier C. Celiac disease. N Engl J Med. 2007;357(17):1731-1743.

12. de Almeida Menezes M, Cabral V, Silva Lorena SL. Celiac crisis in adults: a case report and review of the literature focusing in the prevention of refeeding syndrome. Rev Esp Enferm Dig. 2017; 109(1):67-68.

13. Mones RL, Atienza KV, Youssef NN et el. Celiac Crisis in the Modern Era. J Pediatr Nutr. 2007;45(4):480-483.

14. Kocsis D, CsaplárM, Jócsák $E$ et al. Celiac disease association with other autoimmune disorders: three case reports. Case Rep Int Med. 2015;2:23-9. 